\title{
Pulmonary function in normal Jordanian children
}

\author{
NAIF A SLIMAN, BASEM M DAJANI, KANDIL S SHUBAIR
}

\section{From Jordan University Hospital, Amman, Jordan}

ABSTRACT A sample of 204 male and 224 female healthy Jordanian children was selected to determine the normal ventilatory functions of this Arab population. Forced vital capacity (FVC), one-second forced expiratory volume $\left(\mathrm{FEV}_{1}\right)$, and forced mid-expiratory flow rate (FMFR 25-75\%) were determined with a dry bellows spirometer. Multiple linear regression formulae and correlation coefficients were computed for the group. Jordanian values for FVC and FEV 1 were similar to those of Caucasians living in the Western hemisphere.

Data on pulmonary function in children are scarce. The fact that anthropometric measurements affect the results of lung function tests in children has been shown repeatedly in previous reports. ${ }^{1-7}$ In assessment of pulmonary function measurements of forced vital capacity (FVC), one-second forced expiratory volume $\left(\mathrm{FEV}_{1}\right)$, and forced mid-expiratory flow rate (FMFR 25-75\%) are most commonly used. Such measurements, to be of any clinical value, must be compared with expected normal values for the subject. These values may be influenced by several factors, especially sex, height, age, usual habitat, and ethnic and racial origin. Hence it is necessary to know the normal ranges of these measurements for each racial group, all the other variables being taken into consideration.

We have previously reported standards for pulmonary function test values in healthy adult Jordanians. ${ }^{8}$ Here we report standards for healthy children.

\section{Methods}

Four hundred and twenty-eight healthy Jordanian children (204 boys and 224 girls) ranging in age from 7 to 18 years were tested (table 1). They were selected at random from different elementary and secondary schools in the Amman area. All were Arabs.

The children were healthy non-smokers, receiving no medications and with no recent or earlier history of any respiratory or cardiovascular disease. They were all living in the Amman area, which is 774 metres above sea level.

The FVC, FEV 1 and FMFR 25-75\% were determined in the standing position without a nose clip by means of a Vitalograph dry bellows spirometer (Vitalograph Ltd, Buckingham, England). After adequate training the best of three measurements was used. The ambient temperature and barometric pressure at the time of testing each

Address for reprint requests: Dr Naif A Sliman. Jordan University Hospital. Amman, Jordan. subject were recorded. The lung volumes measured were subsequently computed for body temperature and normal barometric pressure saturated (BTPS), the formulae quoted by Cotes being used. ${ }^{9}$

For the analysis of the results the indices of lung function were expressed as logarithms and regressed on the logarithms of stature and also on the indices of age and weight. The $1 \%$ level of probability was accepted as significant.

\section{Results}

The height of the 204 boys ranged from 110 to $184 \mathrm{~cm}$ and their weight from 17 to $89 \mathrm{~kg}$. The height of the 224 girls ranged from 113 to $171 \mathrm{~cm}$ and their weight from 16 to 82 $\mathrm{kg}$. Because of the major effect of height on pulmonary function test values, we divided the population under study into height groups differing by $5 \mathrm{~cm}$. Means and standard deviations of age, weight, $\mathrm{FVC}, \mathrm{FEV}_{1}, \mathrm{FEV}_{1}$ / FVC\% (FEV $\%$ ), and FMFR $25-75 \%$ for each height ? group of boys and girls are shown in tables 2 and 3 .

The correlations of FVC, $\mathrm{FEV}_{1}, \mathrm{FEV}_{1} \%$, and FMFR 25-75\% with height, age, and weight and with each other were calculated (table 4). $\mathrm{FEV}_{1} \%$ has a poor correlation with all the other pulmonary function values as well as

Table 1 Age and sex distribution of children studied

\begin{tabular}{ccc}
\hline Age $(y)$ & No of boys & Noof girls \\
\hline 7 & 17 & 23 \\
8 & 18 & 31 \\
9 & 20 & 18 \\
10 & 16 & 26 \\
11 & 20 & 33 \\
12 & 14 & 9 \\
13 & 21 & 8 \\
14 & 15 & 13 \\
15 & 15 & 12 \\
16 & 18 & 24 \\
17 & 13 & 17 \\
18 & 17 & 10 \\
Total & 204 & 224 \\
\hline
\end{tabular}


Table 2 Mean values (with standard deviations) for age, height, FVC, FEV , and forced mid-expiratoryflow rate (FMFR)(BTPS) in 204 normal boys in relation to height

\begin{tabular}{|c|c|c|c|c|c|c|c|c|c|c|c|c|c|}
\hline \multirow{3}{*}{$\begin{array}{l}\begin{array}{l}\text { Height } \\
(\mathrm{cm})\end{array} \\
110-114 \\
115-119\end{array}$} & \multirow{2}{*}{$\frac{\text { No }}{2}$} & \multicolumn{2}{|l|}{$\begin{array}{l}\text { Age } \\
\text { (y) }\end{array}$} & \multicolumn{2}{|c|}{$\begin{array}{l}\text { Weight } \\
(k g)\end{array}$} & \multicolumn{2}{|c|}{$\begin{array}{l}F V C \\
\text { (l) }\end{array}$} & \multicolumn{2}{|c|}{$\begin{array}{l}F E V_{\text {, }} \\
\text { (l) }\end{array}$} & \multicolumn{2}{|c|}{$F E V, I F V C \%$} & \multicolumn{2}{|c|}{$\begin{array}{l}F M F R \\
(l / s)\end{array}$} \\
\hline & & $8 \cdot 5$ & $(0 \cdot 7)$ & $18 \cdot 0$ & $(2 \cdot 8)$ & $1 \cdot 5$ & $(0 \cdot 4)$ & $1 \cdot 3$ & $(0 \cdot 4)$ & $84 \cdot 5$ & $(9 \cdot 2)$ & $1 \cdot 6$ & $(0 \cdot 7)$ \\
\hline & 6 & $8 \cdot 3$ & $(2 \cdot 0)$ & $26 \cdot 1$ & $(13 \cdot 3)$ & $2 \cdot 0$ & $(0.6)$ & $1 \cdot 8$ & $(0.5)$ & $91 \cdot 5$ & $(3 \cdot \overline{5})$ & $2 \cdot 3$ & $(0.4)$ \\
\hline $120-124$ & 20 & $7 \cdot 9$ & $(1 \cdot 8)$ & $24 \cdot 7$ & $(9 \cdot 1)$ & $1 \cdot 9$ & $(0.8)$ & $1 \cdot 7$ & $(0.6)$ & $88 \cdot 5$ & $(6.8)$ & $1 \cdot 9$ & $(0 \cdot 7)$ \\
\hline $125-129$ & 18 & $8 \cdot 4$ & $(1 \cdot 2)$ & $26 \cdot 4$ & $(7 \cdot 3)$ & $1 \cdot 9$ & $(0 \cdot 3)$ & $1 \cdot 7$ & $(0 \cdot 3)$ & $89 \cdot 4$ & $(7 \cdot 8)$ & 1.9 & $(0.7)$ \\
\hline $130-134$ & 14 & $9 \cdot 1$ & $(0 \cdot 8)$ & $30 \cdot 2$ & $(8 \cdot 3)$ & $2 \cdot 3$ & $(0 \cdot 2)$ & $2 \cdot 1$ & $(0 \cdot 3)$ & $90 \cdot 3$ & $(8 \cdot 5)$ & 2.6 & $(0 \cdot 6)$ \\
\hline $135-139$ & 23 & $10 \cdot 0$ & $(1 \cdot 4)$ & $29 \cdot 0$ & $(5 \cdot 2)$ & $2 \cdot 3$ & $(0 \cdot 5)$ & $2 \cdot 1$ & $(0 \cdot 4)$ & $90 \cdot 4$ & $(7 \cdot 0)$ & $2 \cdot 5$ & $(0.7)$ \\
\hline $140-144$ & 20 & $11 \cdot 5$ & $(1 \cdot 3)$ & $34 \cdot 0$ & $(5 \cdot 1)$ & $2 \cdot 5$ & $(0.6)$ & $2 \cdot 3$ & $(0.5)$ & $91 \cdot 4$ & $(2 \cdot 7)$ & $3 \cdot 0$ & $(0 \cdot 5)$ \\
\hline $145-149$ & 8 & $11 \cdot 6$ & $(1 \cdot 1)$ & $36 \cdot 4$ & $(2 \cdot 7)$ & $2 \cdot 7$ & $(0 \cdot 2)$ & $2 \cdot 2$ & $(0 \cdot 3)$ & $82 \cdot 1$ & $(6 \cdot 8)$ & $2 \cdot 2$ & $(0 \cdot 6)$ \\
\hline $150-154$ & 14 & $12 \cdot 9$ & $(1 \cdot 1)$ & $43 \cdot 1$ & $(9 \cdot 0)$ & $3 \cdot 2$ & $(0 \cdot 3)$ & 2.9 & $(0.3)$ & $88 \cdot 6$ & $(4 \cdot 7)$ & $3 \cdot 4$ & $(1 \cdot 0)$ \\
\hline $155-159$ & 6 & $13 \cdot 5$ & $(0.8)$ & $49 \cdot 1$ & $(11 \cdot 5)$ & $3 \cdot 6$ & $(0.5)$ & $3 \cdot 2$ & $(0.4)$ & $89 \cdot 8$ & $(6 \cdot 3)$ & $3 \cdot 6$ & $(0.8)$ \\
\hline $160-164$ & 12 & $13 \cdot 7$ & $(1 \cdot 2)$ & $49 \cdot 6$ & $(5 \cdot 0)$ & $3 \cdot 7$ & $(0.5)$ & $3 \cdot 3$ & $(0.5)$ & $89 \cdot 5$ & $(4 \cdot 5)$ & $3 \cdot 8$ & $(0.9)$ \\
\hline $165-169$ & 15 & $16 \cdot 5$ & $(1 \cdot 1)$ & $59 \cdot 0$ & $(9 \cdot 3)$ & $4 \cdot 4$ & $(0.5)$ & 3.9 & $(0.5)$ & 89.7 & $(4 \cdot 5)$ & $4 \cdot 5$ & $(0.8)$ \\
\hline $170-174$ & 19 & $15 \cdot 6$ & $(1 \cdot 7)$ & $60 \cdot 8$ & $(9 \cdot 5)$ & $4 \cdot 7$ & $(0.6)$ & $4 \cdot 3$ & $(0.6)$ & $91 \cdot 1$ & $(6 \cdot 6)$ & $4 \cdot 8$ & $(1 \cdot 5)$ \\
\hline $175-179$ & 21 & $16 \cdot 5$ & $(1 \cdot 4)$ & $66 \cdot 4$ & $(10 \cdot 1)$ & $5 \cdot 5$ & $(0.9)$ & 4.9 & $(0.6)$ & $90 \cdot 3$ & $(9 \cdot 5)$ & $5 \cdot 4$ & $(1 \cdot 0)$ \\
\hline $180-184$ & 6 & 16.7 & $(1 \cdot 0)$ & $75 \cdot 1$ & $(11 \cdot 5)$ & $5 \cdot 8$ & $(0 \cdot 8)$ & $5 \cdot 2$ & $(0 \cdot 8)$ & 89.7 & $(8 \cdot 7)$ & $6 \cdot 1$ & $(2 \cdot 3)$ \\
\hline
\end{tabular}

Table 3 Mean values (with standard deviations) for age, height, FVC, FEV , and forced mid-expiratory flow rate (FMFR)(BTPS) in 224 normal girls in relation to height

\begin{tabular}{|c|c|c|c|c|c|c|c|c|c|c|c|c|c|}
\hline \multirow{2}{*}{$\begin{array}{l}\text { Height } \\
(\mathrm{cm}) \\
110-114\end{array}$} & \multirow{2}{*}{$\frac{N o}{2}$} & \multicolumn{2}{|l|}{$\begin{array}{l}\text { Age } \\
\text { (y) }\end{array}$} & \multicolumn{2}{|c|}{$\begin{array}{l}\text { Weight } \\
(\mathrm{kg})\end{array}$} & \multicolumn{2}{|c|}{$\begin{array}{l}F V C \\
\text { (l) }\end{array}$} & \multicolumn{2}{|c|}{$\begin{array}{l}F E V_{l} \\
(l)\end{array}$} & \multicolumn{2}{|c|}{$F E V, / F V C \%$} & \multicolumn{2}{|c|}{$\begin{array}{l}F M F R \\
(l / s)\end{array}$} \\
\hline & & $7 \cdot 0$ & $(0 \cdot 0)$ & $18 \cdot 0$ & $(0 \cdot 0)$ & $1 \cdot 2$ & $(0 \cdot 0)$ & $1 \cdot 2$ & $(0 \cdot 0)$ & $93 \cdot 2$ & $(1 \cdot 5)$ & $2 \cdot 0$ & $(0 \cdot 4)$ \\
\hline $115-119$ & 12 & $7 \cdot 3$ & $(0.5)$ & $19 \cdot 5$ & $(2 \cdot 0)$ & $1 \cdot 4$ & $(0 \cdot 2)$ & $1 \cdot 4$ & $(2 \cdot 0)$ & 93.3 & $(3.9)$ & $2 \cdot 0$ & $(0.6)$ \\
\hline $120-124$ & 12 & $7 \cdot 8$ & $(0.8)$ & $20 \cdot 3$ & $(1 \cdot 2)$ & 1.6 & $(0 \cdot 2)$ & $1 \cdot 5$ & $(0.2)$ & $92 \cdot 0$ & $(5 \cdot 2)$ & 1.9 & $(0.4)$ \\
\hline $125-129$ & 24 & $8 \cdot 2$ & $(0.8)$ & $25 \cdot 8$ & $(3 \cdot 8)$ & 1.9 & $(0 \cdot 2)$ & 1.7 & $(0 \cdot 2)$ & $90 \cdot 1$ & $(4 \cdot 0)$ & $2 \cdot 0$ & $(0.4)$ \\
\hline $130-134$ & 26 & $9 \cdot 2$ & $(1 \cdot 2)$ & $30 \cdot 1$ & $(10.9)$ & $2 \cdot 0$ & $(0 \cdot 3)$ & $1 \cdot 7$ & $(0.3)$ & $88 \cdot 5$ & $(9 \cdot 4)$ & $2 \cdot 1$ & $(0 \cdot 5)$ \\
\hline $135-139$ & 18 & $9 \cdot \overline{8}$ & $(1 \cdot 2)$ & $33 \cdot 9$ & $(4 \cdot 3)$ & $2 \cdot 2$ & $(0.4)$ & $2 \cdot 0$ & $(0 \cdot 4)$ & $90 \cdot 2$ & $(4 \cdot 9)$ & $2 \cdot 3$ & $(0 \cdot 7)$ \\
\hline $140-144$ & 13 & $11 \cdot 1$ & $(1 \cdot 4)$ & $39 \cdot 8$ & $(12 \cdot 6)$ & $2 \cdot \overline{5}$ & $(0 \cdot 4)$ & $2 \cdot 3$ & $(0 \cdot 3)$ & $91 \cdot 0$ & $(3.9)$ & $3 \cdot 3$ & $(1.8)$ \\
\hline $145-149$ & 15 & $11 \cdot 6$ & $(1 \cdot 8)$ & $42 \cdot 4$ & $(9 \cdot 3)$ & $2 \cdot 9$ & $(0 \cdot 5)$ & $2 \cdot 5$ & $(0 \cdot 3)$ & $88 \cdot 8$ & $(7 \cdot 4)$ & $3 \cdot 0$ & $(1 \cdot 0)$ \\
\hline $150-154$ & 32 & 13.9 & $(2 \cdot 9)$ & $47 \cdot 4$ & $(7 \cdot 1)$ & $3 \cdot 2$ & $(0 \cdot 5)$ & $2 \cdot 9$ & $(0.5)$ & $91 \cdot 7$ & $(7 \cdot 6)$ & 3.8 & $(1 \cdot 1)$ \\
\hline $155-159$ & 33 & $15 \cdot 2$ & $(2 \cdot 2)$ & $51 \cdot 7$ & $(6.6)$ & $3 \cdot 5$ & $(0 \cdot 4)$ & $3 \cdot 3$ & $(0.5)$ & $93 \cdot 2$ & $(8 \cdot 8)$ & $4 \cdot 3$ & $(1 \cdot 3)$ \\
\hline $160-164$ & 20 & $15 \cdot 8$ & $(1 \cdot 1)$ & $56 \cdot 7$ & $(8 \cdot 7)$ & 3.9 & $(0.6)$ & 3.6 & $(0 \cdot 4)$ & 91.9 & $(5 \cdot 2)$ & $4 \cdot 1$ & $(1 \cdot 2)$ \\
\hline $165-169$ & 9 & 15.9 & $(1 \cdot 8)$ & $55 \cdot 4$ & $(7 \cdot 0)$ & $4 \cdot 4$ & $(0.8)$ & $4 \cdot 0$ & $(0.5)$ & $91 \cdot 2$ & $(6 \cdot 3)$ & $4 \cdot 5$ & $(0.8)$ \\
\hline $170-174$ & 8 & 16.0 & $(0 \cdot 0)$ & $64 \cdot 0$ & $(12 \cdot 3)$ & $4 \cdot 5$ & $(0 \cdot 3)$ & $4 \cdot 0$ & $(0 \cdot 2)$ & 90.5 & $(7 \cdot 7)$ & $5 \cdot 0$ & $(0 \cdot 4)$ \\
\hline
\end{tabular}

with age, height, and weight. This was true for both boys and girls. Table 4 , however, shows a good correlation between height and all the functions measured, except for $\mathrm{FEV}_{1} \%$, in boys; in general, the correlations were poorer in girls.

The figure shows the relation of $\mathrm{FEV}_{1}$ to age in both boys and girls. FEV 1 progressively increases with age in

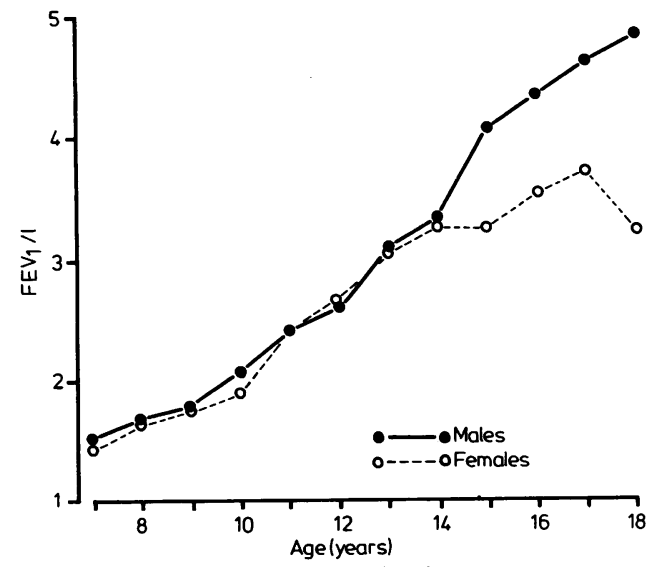

Relation of FEV, to age in boys and girls. boys up to 18 years, while it levels off in girls at the age of 15.

The relation of lung function indices to height are shown in table 5 . The formulae thus shown can be applied to boys as well as girls. Girls have lower values for flow rates.

When other anthropometric measurements are added to the relationships, as shown in table 6 , the difference between boys and girls is still evident. Certain coefficients, as is seen from these relationships, had very low numerical values. The coefficients for age and weight over height squared $\left(\mathrm{Wt} / \mathrm{Ht}^{2}\right.$ ) for both boys and girls were therefore subjected to statistical analysis with the Student's $t$ test (table 7). After height has been allowed for the indices for boys are seen to depend more on $\mathrm{Wt} / \mathrm{Ht}^{2}$ than on age, while the reverse is true for girls. None of the coefficients was found to be significant in relation to $\mathrm{FEV}_{1} \%$.

\section{Discussion}

The population studied was chosen randomly from schoolchildren in the Amman area, the youngest being 7 years of age. Below this age it is difficult to get the co-operation of the child, since the indices we are 
Table 4 Correlation coefficients between pulmonary function measurements in normal Jordanian children aged 5-18 years

\begin{tabular}{|c|c|c|c|c|c|c|c|c|}
\hline Measurement & Sex & Height & Age & Weight & $F V C$ & $F E V_{1}$ & $F E V, / F V C \%$ & $F M F R$ \\
\hline Height & $\begin{array}{l}\mathrm{M} \\
\mathrm{F}\end{array}$ & $\begin{array}{l}1.00 \\
1.00\end{array}$ & $\begin{array}{l}0.907 \\
0.455\end{array}$ & $\begin{array}{l}0.871 \\
0.416\end{array}$ & $\begin{array}{l}0.891 \\
0.432\end{array}$ & $\begin{array}{l}0.902 \\
0.430\end{array}$ & $\begin{array}{l}0.054 \\
0.014\end{array}$ & $\begin{array}{l}0.787 \\
0.323\end{array}$ \\
\hline Age & $\begin{array}{l}\mathbf{M} \\
\mathbf{F}\end{array}$ & & $\begin{array}{l}1.00 \\
1.00\end{array}$ & $\begin{array}{l}0.855 \\
0.837\end{array}$ & $\begin{array}{l}0 \cdot 854 \\
0 \cdot 874\end{array}$ & $\begin{array}{l}0.874 \\
0.879\end{array}$ & $\begin{array}{l}0 \cdot 074 \\
0 \cdot 087\end{array}$ & $\begin{array}{l}0.778 \\
0.728\end{array}$ \\
\hline Weight & $\begin{array}{l}\mathbf{M} \\
\mathbf{F}\end{array}$ & & & $\begin{array}{l}1 \cdot 00 \\
1.00\end{array}$ & $\begin{array}{l}0.894 \\
0.865\end{array}$ & $\begin{array}{l}0.902 \\
0 \cdot 848\end{array}$ & $\begin{array}{l}0.031 \\
0.008\end{array}$ & $\begin{array}{l}0.759 \\
0.836\end{array}$ \\
\hline FVC & $\begin{array}{l}\mathbf{M} \\
\mathbf{F}\end{array}$ & & & & $\begin{array}{l}1.00 \\
1.00\end{array}$ & $\begin{array}{l}0.973 \\
0.972\end{array}$ & $\begin{array}{l}0.072 \\
0.035\end{array}$ & $\begin{array}{l}0.800 \\
0.700\end{array}$ \\
\hline $\mathrm{FEV}_{1}$ & $\begin{array}{l}\mathbf{M} \\
\mathbf{F}\end{array}$ & & & & & $\begin{array}{l}1.00 \\
1.00\end{array}$ & $\begin{array}{l}0 \cdot 127 \\
0 \cdot 192\end{array}$ & $\begin{array}{l}0.869 \\
0.766\end{array}$ \\
\hline FEV,$\% / F V C$ & $\begin{array}{l}\mathrm{M} \\
\mathrm{F}\end{array}$ & & & & & & $\begin{array}{l}1.00 \\
1.00\end{array}$ & $\begin{array}{l}0.367 \\
0.319\end{array}$ \\
\hline FMF & $\mathbf{M}$ & & & & & & & $\begin{array}{l}1.00 \\
1.00\end{array}$ \\
\hline
\end{tabular}

Table 5 Regression relationships of indices of lung function to height in the form $\log _{e}$ index $=\mathrm{a} \log _{e} H \mathrm{t}(\mathrm{cm})+\mathrm{b}+\mathrm{c} \mathrm{sex}$, where the sex term is 0 for boys and 1 for girls

\begin{tabular}{|c|c|c|c|c|}
\hline & $a$ & b & $c^{*}$ & SD' \\
\hline $\begin{array}{l}\text { FVC (l) } \\
\text { FEV, (l) } \\
\text { FEV, } / F V C \% \\
\text { FMFR }(1 / s)\end{array}$ & $\begin{array}{l}2 \cdot 818 \\
2 \cdot 836 \\
0 \cdot 018 \\
2 \cdot 674\end{array}$ & $\begin{array}{r}-12 \cdot 894 \\
-13 \cdot 184 \\
4 \cdot 405 \\
-12 \cdot 242\end{array}$ & $\begin{array}{r}-0.118 \\
-0.011 \\
0.013 \\
0.034\end{array}$ & $\begin{array}{l}0.234 \\
0.231 \\
0.080 \\
0.297\end{array}$ \\
\hline
\end{tabular}

*The coefficient $\mathrm{c}$ is also the fractional difference in the index bet ween boys and girls of the same height.

tStandard deviation of $\log _{e}$ index about relationship.

Table 6 Regression relationships of lung function on height $(\mathrm{cm})$, age (y), and weight/height ${ }^{2}\left(\mathrm{~kg} / \mathrm{m}^{2}\right)$ for boys and girls in the form $\log _{e}$ index $=\mathrm{a} \log _{e}$ height $+\mathrm{b}$ age $+\mathrm{c}$ weight $/$ height ${ }^{2}+\mathrm{d}+$ e sex, where the sex term is 0 for boys and I for girls

\begin{tabular}{lclllll}
\hline & $\mathrm{a}$ & $\mathrm{b}$ & $\mathrm{c}$ & $\mathrm{d}$ & $\mathrm{e}$ & SD $^{*}$ \\
\hline FVC (l) & 2.413 & 0.004 & 0.024 & -11.46 & -0.91 & 0.210 \\
FEV $_{\text {, (l) }}$ & 2.298 & 0.011 & 0.023 & -11.05 & -0.005 & 0.208 \\
FEV /FVC\% & -0.115 & 0.007 & -0.0016 & 5.015 & 0.1 & 0.080 \\
FMFR (l/s) & 1.441 & 0.048 & 0.010 & -6.858 & 0.035 & 0.282 \\
\hline
\end{tabular}

*Standard deviation of $\log _{e}$ index about relationship.

Table 7 Contributions of age and weight/height ${ }^{2}$ to the description of lung function in children

\begin{tabular}{lllll}
\hline & Boys & & Girls \\
\cline { 2 - 5 } & Age & Wt $/ h t^{2}$ & Age & $W t / h t^{2}$ \\
\hline FVC (l) & NS & + & + & $(+)$ \\
FEV $(1)$ & NS & + & + & $(+)$ \\
FEV $/$ /FVC\% & NS & NS & NS & NS \\
FMFR (l/s) & + & $(+)$ & + & NS
\end{tabular}

NS - not significant. + and - indicate a significant regression coef ficient on the variable in question after height has been allowed for. Where more than one term is significant, the one that gives the less good fit is indicated by parentheses. measuring are effort dependent. Although no statistical methods were used to choose the children, the number studied and the fact that many schools in different areas of $\vec{\oplus}$ the city were included give a reasonable degree of $N$ confidence in the data. All the children were Arabs. Thus in the absence of any other published data from the Arab world these data may be used as standards of pulmonary function test values for Arab children elsewhere, provided that the factor of altitude is taken into account, Amman being 774 metres above sea level, as well as the fact that these data were derived from an urban population.

Unlike in adults, where weight has no significant effect on FVC, FEV , and FMFR 25-75\%. ${ }^{5-10}$ our data show that in children weight seems to play an additional part in influencing the results of the pulmonary function tests. This observation is supported by data from other workers. $^{2} 41112$ Our data show that age, height, and weight play almost equal parts in modulating the results of pulmonary function tests; this makes sense becauseagain unlike in adults - these three indices go hand in hand in children.

When $\mathrm{FEV}_{1}$ was plotted against age (fig) trends were $\stackrel{\circ}{?}$ noted. Firstly, there is sharp rise of FEV $\mathrm{Fi}_{1}$ both boys and girls similar to that observed by Cotes. ${ }^{9}$ Secondly, girls show a levelling off at the age of 15 and beyond unlike $N$ boys, whose $\mathrm{FEV}_{1}$ continues to increase with age. This $\mathrm{N}$ phenomenon, though noted by Strang in $1959,{ }^{1}$ has not $N$ been considered by other authors. These two facts should therefore be taken into consideration whenever standards of pulmonary function test values are used for assessing $\stackrel{\circ}{E}$ disease states or for comparing different populations.

To assess the pulmonary function of a particular adult the observer usually refers to nomograms or linear regression curves. In children, however, these two $\underset{\mathbb{D}}{\mathrm{D}}$ methods cannot be used because other factors not $\stackrel{?}{?}$ represented in such computations have an important $\varrho$ 
role-namely, weight and the growth spurt. Multiple linear regression formulae are thus better. A crude but simple index is the $\mathrm{FEV}_{1} \%$. Our data show that it has no correlation with anthropometric measurements or the result of other pulmonary function tests. An FEV $\%$ over $85 \%$ probably indicates normal pulmonary function (if restrictive pulmonary diseases have beeh excluded).

Our data show that the correlation coefficients for height versus all the other indices are higher in boys than girls. Although Woolcook et $a l^{5}$ reported completely different observations, Dugdale and Moeri ${ }^{2}$ and Dickman et $a l^{4}$ obtained results similar to ours. The explanation for the low correlation with height in girls may be related to sampling, levelling of growth at the age of 15 (as discussed above), or other factors unknown to us.

We compared the pulmonary function tests values of Jordanian children with those from other ethnic groups as reported by Polgar and Promadhat ${ }^{13}$ for European, Cotes ${ }^{9}$ and Strang ${ }^{1}$ for British, and Dickman et al ${ }^{4}$ for white American children and Bhattacharya and Banerjee ${ }^{14}$ for children of Indian descent. Just as the Jordanian adults we studied previously ${ }^{8}$ proved to be similar to other ethnic groups, the population values for our children are very similar to the values obtained in these other sturdies.

\section{References}

' Strang LB. The ventilatory capacity of normal children. Thorax 1959;14:305-10.

${ }^{2}$ Dugdale AE, Moeri M. Normal values of forced vital capacity
(FVC), forced expiratory volume $\left(\mathrm{FEV}_{1}\right)$, and peak flow rate (PFR) in children. Arch Dis Child 1968;43:229-34.

${ }^{3}$ Weng TR, Levison H. Standards of pulmonary function in children. Am Rev Respir Dis 1969;99:879-94.

${ }^{4}$ Dickman ML, Schmidt CD. Gardner RM. Spirometric standards for normal children and adolescents (aged 5 years through 18 years). Am Rev Respir Dis 1971;104:680-7.

5 Woolcook AJ, Colman MH, Blackburn CRB. Factors affecting normal values for ventilatory lung function. Am Rev Respir Dis 1972;106:692-709.

${ }^{6}$ Higgins MW, Keller JB. Seven measures of ventilatory lung function. Am Rev Respir Dis 1973;108:258-71.

${ }^{7}$ Cotes JE, Dabbs, JM, Hall AM, Heywood C. Sitting height, fat-free mass and body fat as reference variables for lung function in healthy British children: comparison with stature. Ann Hum Bio 1979;6:307-14.

${ }^{8}$ Sliman NA, Dajani BM, Dajani HM. Ventilatory function test values of healthy adult Jordanians. Thorax 1981;36:546-9.

${ }^{9}$ Cotes JE. Lung function: assessment and application in medicine. 4th ed. Oxford: Blackwell Scientific Publications. 1979.

1) Cotes JE, Rossiter CE, Higgins ITT. Gilson JE. Average normal values for forced expiratory volume in white caucasian males. Br Med J 1966;i:1016-9.

"Chetty A. Ghai OP, Gularia JS. Pulmonary function studies in normal children. Indian Pediatrics 1975;12:647-51.

12 Helliesen PJ, Cool CD. Friedlander L, Agathon S. Studies of respiratory physiology in children. I-Mechanics of respiration and lung volumes in 85 normal children 5 to 17 years of age. Pediatrics 1958;22:80-93.

${ }^{13}$ Polgar G, Promadhat V. Pulmonary function testing in children: techniques and standards. Philadelphia: WB Saunders, 1971.

${ }^{14}$ Bhattacharya AK, Banerjee S. Vital capacity in children and young adults of India. Indian J Med Res 1966:54:62-71. 